\title{
The economic sustainability in urban planning: the case of La Manga
}

\author{
J. L. Miralles ${ }^{1}$ \& S. García-Ayllón ${ }^{2}$ \\ ${ }^{1}$ Polytechnic University of Valencia, Spain \\ ${ }^{2}$ Polytechnic University of Cartagena, Spain
}

\begin{abstract}
The urbanization process that shapes the present Mediterranean coast started with the mass tourism that encouraged the Centres and Areas of National Tourist Interest law in 1962, as a strategic national investment. 50 years after its implementation, it is necessary to conduct a retrospective analysis of the results, assessing to what extent have the stated goals in the 1960s been met. The evolution of the macroeconomic, political and legal parameters show certain deviations from initial forecasts of many large urban plans carried out in coastal places created from scratch. The case of La Manga del Mar Menor on the Murcia coast - a target for 250,000 holidaymakers - which came from a desert dune in the 1960s, is certainly an example; poorly documented while enlightening, of the results that have been achieved. The study of real social and economic performance as a tourism product against territorial and landscape impacts, the problem of governance in the context of urban planning and the ability of private property to develop its own sustainable projects in the long run has been approached with the detail and objectivity that allows a comprehensive case study contrasted by the facts. All these elements will be distributed to either side of the balance, in order to evaluate the validity of a coastal development model, that after five decades we can now begin to postulate with enough research perspective.

Keywords: urban planning, urban management, tourism development, coastal development.
\end{abstract}




\section{Introduction}

La Manga del Mar Menor is a dune line over 20 kilometres in length and a width ranging from 500 meters, at the beginning, to 80 meters at the end. La Manga is located between the Mediterranean Sea and the Mar Menor. The Mar Menor is a salty lagoon of over $170 \mathrm{~km}^{2}$ and drafts uniform 4 or 5 feet deep.

In 1959 the Spanish government is on the brink of default. To obtain foreign credits is forced to implement an economic development plan. This plan provides for the promotion of tourism. La Manga zone's is selected to promote a great project of tourism development.

This case of urban development for holiday resort on the Mediterranean coast is paradigmatic and has been investigated by a $\mathrm{PhD}$ thesis [1]. This paper explains the conclusions of this research about the urban development processes since initial master plan until today when there is a big tourist area with capacity for 250,000 visitors. In other paper presented at the 3rd International Conference on Physical Coastal Processes, Management and Engineering (in press) the authors explain the changes on coastal landscape and marine ecosystems.

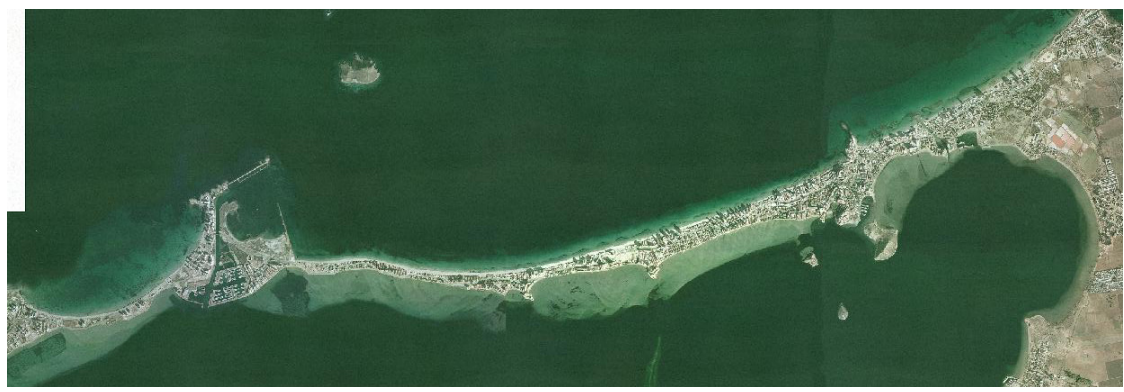

Figure 1: The Manga of Mar Menor today. Origin: Google Earth.

\section{The initial master plan: Bonet plan}

In 1950, the Manga of Mar Menor was a long line of sand with two beaches of $20 \mathrm{~km}$ on two seas. This place attracted the interest of a visionary promoter in the late 1950s.

In the early 1960s, the Franco Spanish government initiated a policy of foreign exchange earnings through the "enhancement" of the coast. The policy is implemented through the Law National Tourist Interest Centres and Areas (hereafter LCZITN) in 1962. The law allows rapid urbanization in different strategic coastal areas as exception of general planning regulations (Land Act of 1956). The selected areas receive financial aid and state grants. The aim is oriented to create urban infrastructure and resorts of quality for foreign tourism with high purchasing power. La Manga is included in the selected list along with other places like Marbella in Malaga, Son Parc in Baleares, Campoamor and La Zenia in Alacant or Sotogrande in Cadiz [2]. 
The projects and development works of the tourist areas, with State subsidies, are awarded to the private sector. Often, the management of projects in each area is done by a single developer well connected with the government, for example in the case of José Banús, the developer of Marbella, or Tomas Maestre, the developer of La Manga. Tomás Maestre commissioned the master plan of La Manga to Antoni Bonet, an internationally renowned architect with experience in large projects in South America such as Buenos Aires General Plan or the Plan of Punta Ballena in Uruguay.

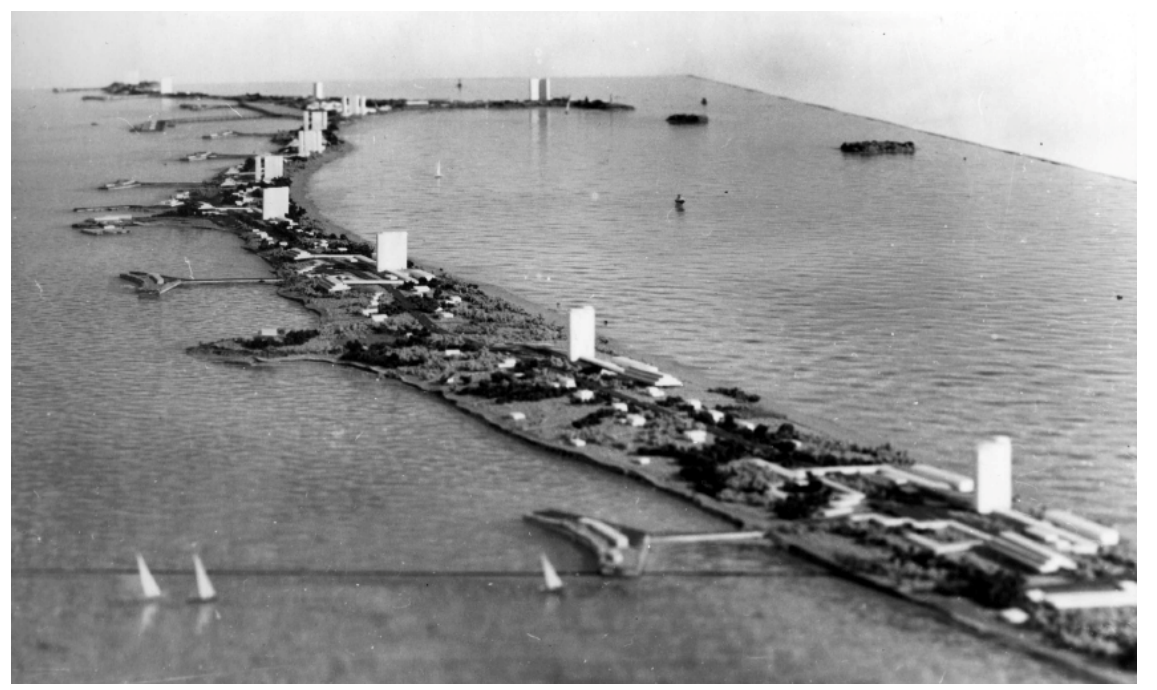

Figure 2: $\quad$ Model of the master plan for La Manga of A Bonet filed in 1963 to Minister Manuel Fraga. Origin: Archive of José Parra.

A. Bonet projects a city born from nothing, designed for a maximum population of 60,000 . The city is designed with infrastructure and services oriented to tourism with high purchasing power. The urban design and land consumption, despite the opposition of the developer T. Maestre, following the modernist principles of the Athens Charter of 1933. The sustainability of the proceedings and the reasonable use of space will generate a structured urban fabric that alternates a skyline of high and low density (Figure 2).

This configuration frees maintaining visual quality in environmental quality, zoning enabling integration of endowments, facilities and public spaces, and implements a rational management of urban traffic, all in a difficult space management. Possible seasonality of demand, with peaks in summer and vacant in winter, is mitigated "making" a city with a population stable base of 15,000 and 60,000 summer peaks.

This urban project runs easily by programmed Bonet Plan and strong financial contribution of public subsidies provided by LCZITN. State investment was more than 11,000 million pesetas divided into four lots (Table 1). 
Table 1: Approval of public investment in La Manga. Origin: Official State Gazette.

\begin{tabular}{|l|c|c|c|c|}
\hline \multicolumn{1}{|c|}{ Project } & $\begin{array}{c}\text { Approved } \\
\text { date, Official } \\
\text { Gazette }\end{array}$ & $\begin{array}{c}\text { Surface } \\
\text { (ha) }\end{array}$ & $\begin{array}{c}\text { Capacity } \\
\text { (num. inhab) }\end{array}$ & $\begin{array}{c}\text { Public } \\
\text { investment } \\
\text { (M pesetas) }\end{array}$ \\
\hline $\begin{array}{l}\text { La Manga Ranch } \\
\text { in Cartagena }\end{array}$ & $12-9-1966$ & 88 & 16,920 & 2,200 \\
\hline $\begin{array}{l}\text { La Manga Ranch } \\
\text { in San Javier }\end{array}$ & $27-1-1969$ & 280 & 36,400 & 8,980 \\
\hline $\begin{array}{l}\text { Honda Beach } \\
\text { (La Manga) }\end{array}$ & $11-2-1967$ & 55 & 4,500 & 296 \\
\hline $\begin{array}{l}\text { Dos Mares Ranch } \\
\text { (La Manga) }\end{array}$ & $25-2-1969$ & 61 & 1,900 & 47 \\
\hline
\end{tabular}

Public funding allows T Maestre to create a network of companies. With the sale of plots and buildings for facilities and hotels, $\mathrm{T}$ Maestre executes infrastructure works and generates substantial capital gains. The LCZITN allows a large degree of freedom to the authorized project managers. All phases of the master plan are started in just 10 years.
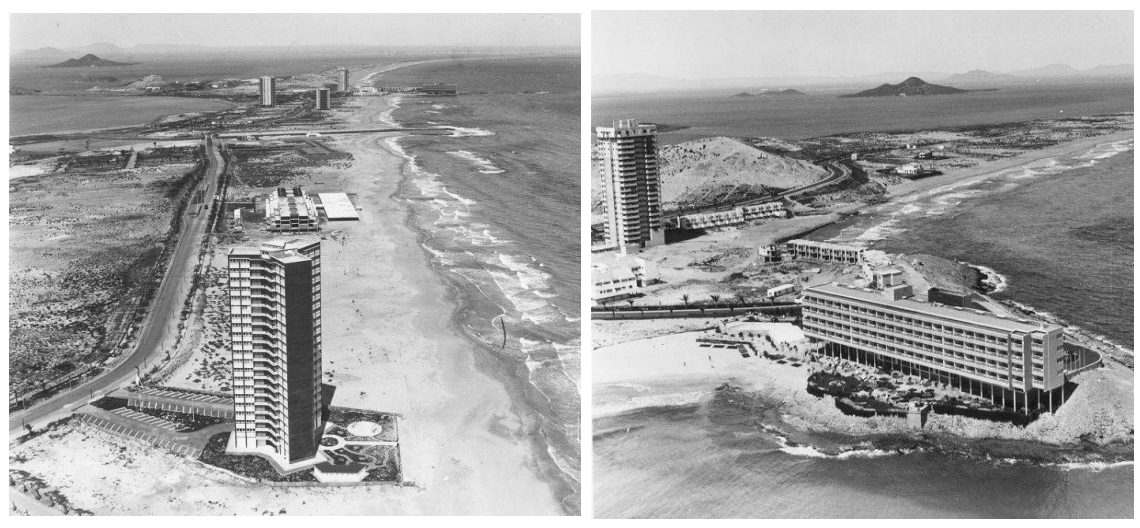

Figure 3: Infrastructure works and buildings in La Manga in the 1960s. Origin: Archive of San Javier.

The elitist environment and economic growth of the 1960s placed at La Manga as an international tourist destination class. Ambitious projects are promoted as casinos, marinas, artificial islands, a beachfront airport and originals architectural proposals.

The architectural quality of the urban proposal attracts wealthy clients and architects that dot the urban space of the most significant works of modernism in the Region of Murcia. The urban plan user stratified into two levels of purchasing power: one mid-level who stay in hotels and high-density residential 
units of $3 \mathrm{~m}^{3} / \mathrm{m}^{2}$ and a more exclusive property acquired in single-family parcels minimum size of 600 to $2000 \mathrm{~m}^{2}$ with a building on $0.5 \mathrm{~m}^{3} / \mathrm{m}^{2}$.

\section{The crisis of the 1970s: tourist and urban consequences}

From 1959 to the economic crisis of 1972 in Spain, the government prioritizes the economic growth. This paradigm is called "developmentalism". The term means to promote at each moment economic development above all else.
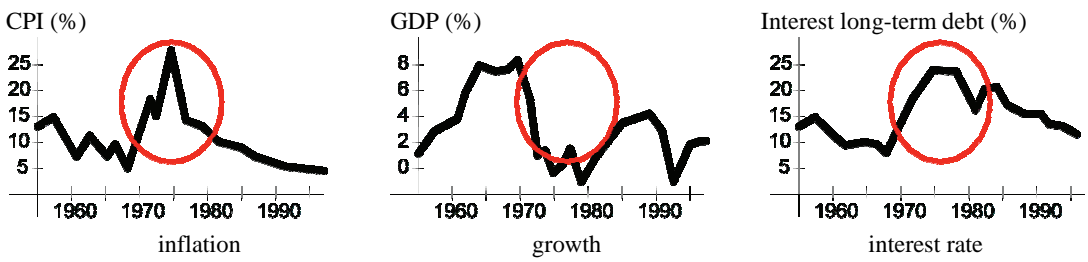

Figure 4: Evolution of the Spanish economy from 1950 to 2000. Origin: official data and authors.

The "developmentalism" of the 1960s is truncated in the middle stage of growth in 1972 by the oil crisis. In Spain, although the crisis takes a little longer to arrive, their consequences are as strong as in the rest of Europe. The GDP fell to negative levels while prices and interest rates reach values of 25\% (Figure 4).

In the case of La Manga, the loss of public funding is lethal to the network of companies created by the developer Maestre to develop his macro-project. In addition there is a reduction of revenue by falling sales generated by the crisis. Therefore, the developer must pay his debts to small and medium local contractors through land. So he paid his debts with building plots produced with the urbanization of the $20 \mathrm{~km}$ of the dune line.

This is therefore an example of overflow: a macro-project too big that, sooner or later, the promoter cannot continue. So the same developer sows the seed of a process that, years later, will end in a chaotic urban hypertrophy.

In a few years, small and medium local contractors paid with building plots become a little greedy bourgeois estate. Moreover, the arrival of democracy in Spain brings a process of administrative decentralization that gives the urban management to municipalities and autonomous regions. The municipalities are in the process of urban expansion a source of short-term income. Then it generates a new urbanization process, regardless of the initial Bonet plan.

La Manga is then converted, with the complicity of local authorities, in a "Taifa urban kingdom" impossible to govern which initiates a chaotic urbanization (outlawed in many cases). The urban area density increases and gets crowded. Urban gaps are built. The landscape becomes an accumulation of buildings. 
Table 2: Hotel beds and not hotel beds in La Manga until 1988. Origin: López-Morell et al. [3].

\begin{tabular}{|c|c|c|c|}
\hline Year & $\begin{array}{c}\text { Not hotel } \\
\text { beds }\end{array}$ & Hotel beds & TOTAL \\
\hline 1965 & 820 & 0 & 820 \\
\hline 1966 & 1.528 & 217 & 1.745 \\
\hline 1967 & 3.193 & 563 & 3.756 \\
\hline 1972 & 18.228 & 563 & 18.791 \\
\hline 1973 & 23.180 & 1.586 & 24.766 \\
\hline 1977 & 40.727 & 1.586 & 42.313 \\
\hline 1978 & 42.272 & 2.521 & 44.793 \\
\hline 1984 & 62.110 & 2.521 & 64.631 \\
\hline 1985 & 65.045 & 2.577 & 67.622 \\
\hline 1988 & 97.004 & 2.577 & 99.576 \\
\hline Percentage & $\mathbf{9 7 , 4 \%}$ & $\mathbf{2 , 6 \%}$ & $\mathbf{1 0 0 \%}$ \\
\hline
\end{tabular}

The first tourist target (with high purchasing power) initiates a difficult cohabitation with a new tourist profile local, less affluent and own a second home cheaply. Finally, the mixture of tourists of different levels is impossible and tourists with high purchasing will be elsewhere.

One indicator of this process is the number of beds and the relationship between hotel beds and not hotel beds (second home) that you can see in Table 2. So in the late 1970s has reached the initial target population of 60,000 beds established in Bonet plan. The target is reached because of the extraordinary growth of second homes. The hotels go to represent $15 \%$ of the beds at the end of the 1960 s to $2.6 \%$ in 1988 . So while growth hotel beds stagnate, residential development continues and in 1988 reached a total of 97,004 beds, the $97.4 \%$ of total beds.

\section{The 1980s and jurisdictional conflicts: the complex urban governance in Spain}

In 1978, Spain adopted its new democratic Constitution. Then, the two levels of local and central government are transformed into three levels: local, regional and central. Before 1978, the central government had competence to approve urban laws. And municipalities, with control of the central government, had full competence in planning, urban management and planning discipline. After 1978, 
the regional administration acquires the competences to approve urban laws and municipalities maintain their competences.

In the initial period of the new constitution, while the new regional administration starts, the stakeholders pressure on municipalities to facilitate land speculation and increased building permits (not always legal). So in coastal areas, administrative decentralization and potential economic development associated to tourism, makes a society that seeks wealth in the short term through capital gains urban. But this causes the development of a low-value tourism model in the long term. In fact, at this time, there was a drop in tourism demand in the area.

In this situation, in 1988, the central government approved a Coastal Act which provides for the protection of a band of 100 meters from the sea-land line (dividing line between the public domain of the sea and land ownership private). This protection directly affects the La Manga strip. Then the Murcia Regional Government approves a regional planning law.

Furthermore, in order to stop the urban chaos of La Manga, the Murcia regional government decided to suspend the processing of planning regulations that replaced Bonet Plan and repealing, retroactively, hundreds of building permits issued by municipalities. This decision creates the outright rejection of the small and medium entrepreneurs and promoters of the construction sector.

Municipalities decide to act on behalf of entrepreneurs and developers and brought before the courts a jurisdiction conflict. They demand that the regional government cannot override their decisions retroactively. We must remember that, in Spain, municipalities can obtain high incomes to urban development.

Finally, municipalities and developers win the case. The court invalidated the retroactive nature of the shares and recognized vested rights as building permits. With this judgment, in La Manga and many other areas of the Spanish coast, consolidates a process of urban overcrowding.

\section{Historical analysis of the socio-economic process}

Since 1990 there has been overcrowding in many tourist areas of the Mediterranean coast. In these areas there is an urban hypertrophy.

In the case of La Manga, this hypertrophy (currently more than 250,000 beds) leads to an impoverishment of urban development as a tourism product. This statement is justified on three types of indicators: visual, urban and economic.

First, let's talk about the visual effects produced by changing urban model of the late 1970s. The mass of buildings is at the expense of eliminating the alternating low and high density initially projected. This alternation between build and not build zones, allow visual release on both sides. But the mass of buildings along both coastlines has been a claustrophobic effect screen.

On the other hand, the disappearance of the high purchasing power tourist is reflected in dismantling part of the urban fabric of low-density single-family residential. In addition other recreational infrastructure initially project such as the bullring, the airport project and the lakeside city of Veneciola, which are replaced by medium density residential blocks. Besides another buildings such as 
casinos or hotels, whose construction began, are abandoned despite the continued growth of La Manga. Today they are ghostly form a mass of brick and concrete that remains as a vestige of the past (Figure 5).

Second, there are clear indicators of the process of urban decline in value due to the model change. In particular, the rate of occupation of land or land valuation can observe clearly depletion factors of La Manga as a tourism product (Figures 6 and 7).

Gradual consumption soil accelerates in urban overcrowding period. However, if we look at the indicators separately for the south and north, you can see significant effects.

On one hand, you can see as the great land consumption is concentrated in the years after the term of Bonet plan. Consequently, the south is completely saturated and overcrowding produce the subsequent fall in construction activity.

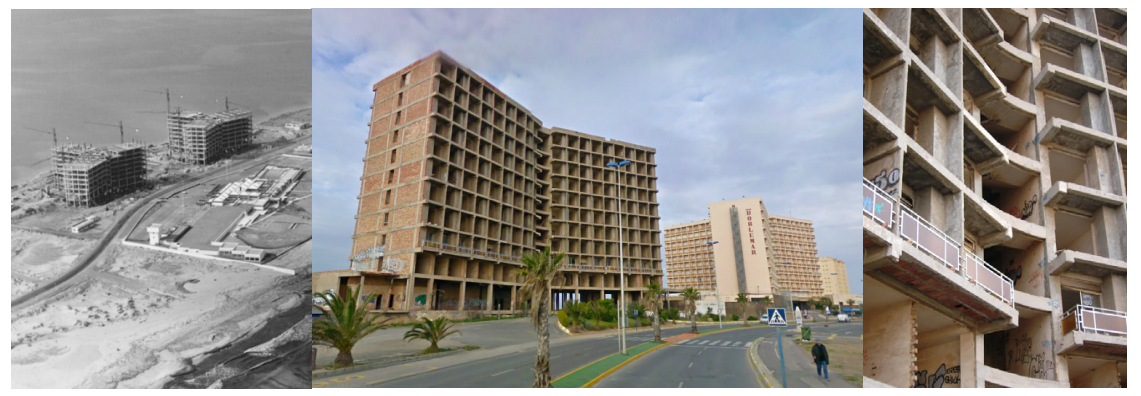

Figure 5: Construction (about 1970) and abandonment a part of Casino Dos Mares. Origin: Archive VECOS promoter and photo authors.
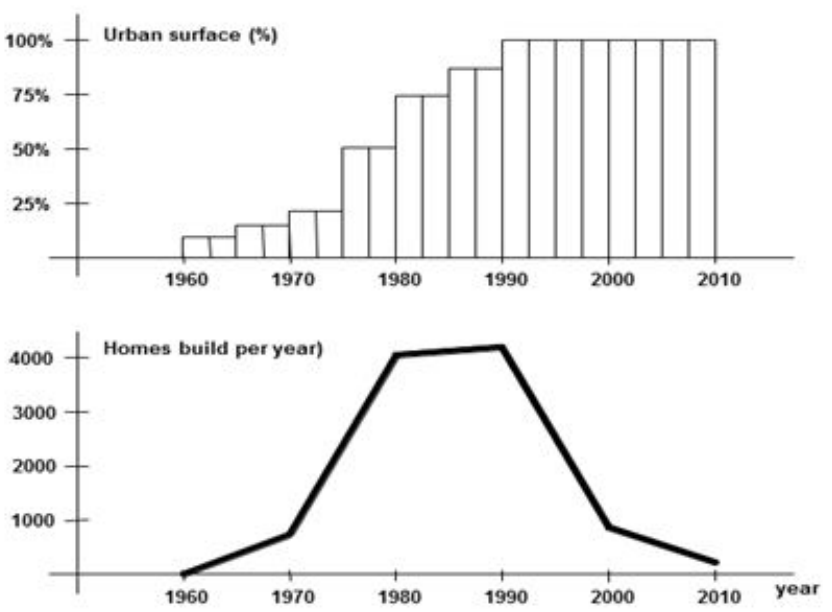

Figure 6: Evolution of artificial surface and build construction in south zone of La Manga. Origin: the authors. 

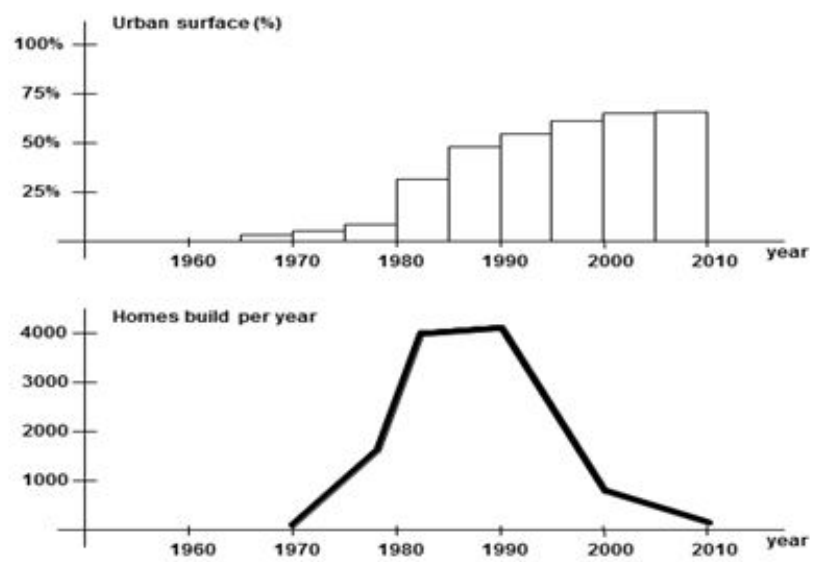

Figure 7: Evolution of artificial surface and build construction in the north zone of La Manga. Origin: the authors.

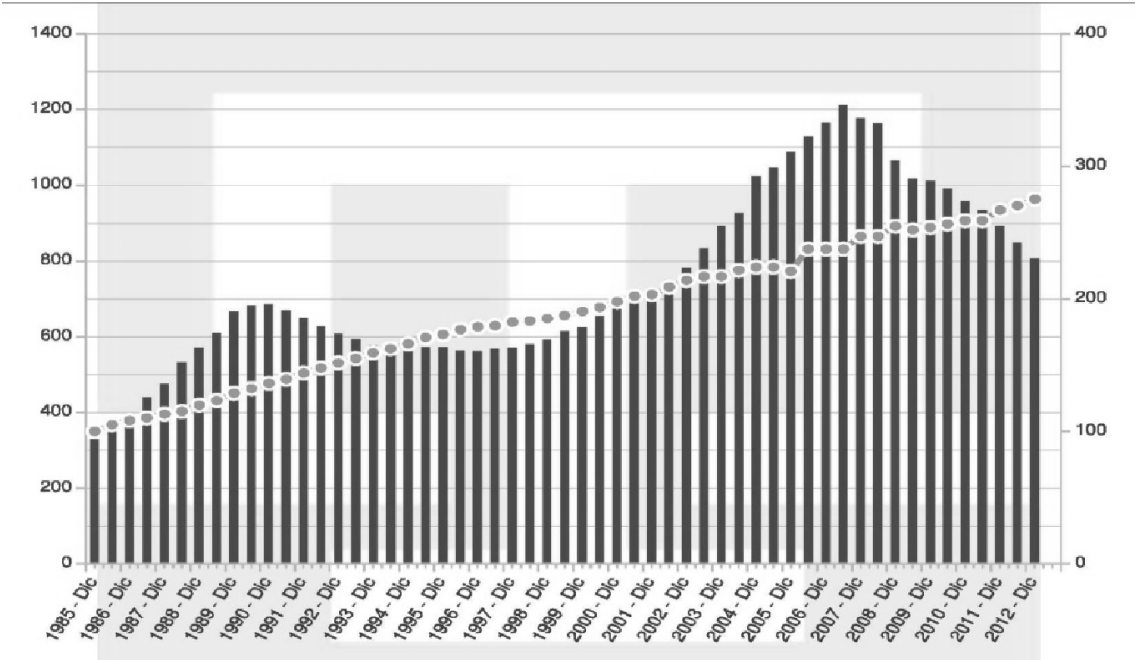

Figure 8: Evolution in Spain of average real price of houses (Euros $/ \mathrm{m}^{2}$, left) and increased accumulation of CPI (\%, right). Origin: Sociedad de Tasación [6].

But in the north, the construction curve is shifted in time. In fact the development works in La Manga were performed sequentially starting from the south and moving north. You can see as in the northern maintaining the concentration of construction activity in the 1980s and early 1990s. However, in the late 1990s, although the urban surface was only $60 \%$ (versus $100 \%$ in the South), the construction activity was paralyzed. 
That is, the brand of La Manga as a tourism product is no longer attractive and demand for new residential tourist construction disappears.

The fact is indicative of a loss of land value, which happens to be a product with a high value (speculative value based on expectations) to be a product with low market demand and therefore of little value. These events are repeated in many other parts of the Spanish Mediterranean coast [4].

So we have an economic indicators for describe the process. Looking at (Figure 8) the evolution of the average selling price of homes and the evolution of the Consumer Price Index (CPI), one can identify speculative behavior of the housing market because of price increases (in the order of $12 \%$ per year on expansive period) are well above the CPI increase (of around 3\% per year) [5].

Additionally you can see (Figure 9) the evolution of the number of dwellings completed each year in Spain and its Mediterranean coast.

In both indicators you can see a valley in the early 1990s which corresponds to the 1991-1996 crisis period, strong growth in the 1997-2007 period that corresponds to the "boom" real estate and a sharp decline since 2007 which corresponds with the period of the current crisis.

This effect is heightened on the Mediterranean coast which usually finds over $40 \%$ of homes built each year.

The collapse in the value of housing in the Spanish Mediterranean coast occurs since 2007. But in the case of La Manga this effect is attenuated, not better resistance to the crisis, but because the impairment as real estate asset was already anticipated in the previous decade by the above reasons.

The case of La Manga raises two key issues. The returns, income and foreign exchange earned by tourism justify the investments made during the 1960s and 1970s?

And again, if we consider social variables such as employment generation, increased local wealth, generation of local production network; is the investment justified?

The answers are not clear. In fact many urban developments on the Spanish Mediterranean coast have generated strong environmental, social and economic impacts [8].

At La Manga, the change of urban model and the urban overcrowding certainly have produced a complex unsustainable. The large residential growth (four times higher than forecast in the Bonet plan) was performed without executing, the same time, the infrastructures and facilities that tourist need or want. This has caused the flight of visitors with high purchasing power that are contributing the most revenue.

Using the methodology of the evaluation of the planning cost to future [9] is seen as an excessive turnover of the urban project as a tourism product, not produce higher profits or economic or social.

Evolutions of the average daily expenditure per tourist (Figure 10) confirm the hypothesis, in case of La Manga, of diminishing returns and depletion of the life cycle of urban development as a tourism product. So, at this moment, it is very complicated to return the situation and change the model for increased income in the area. 


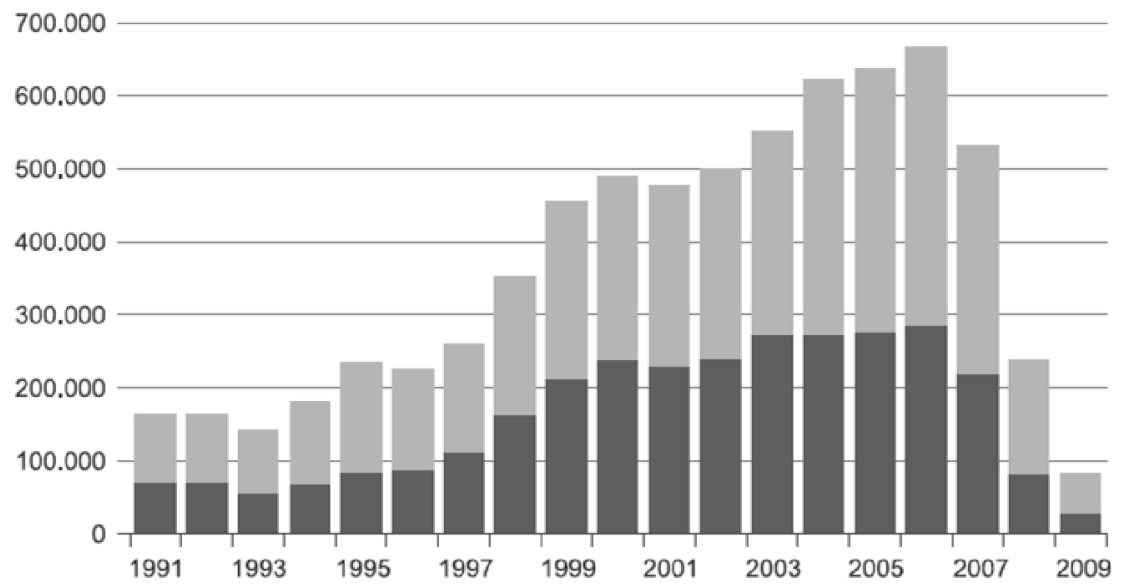

Figure 9: Number of houses finished each year in Spain and the Spanish Mediterranean coast. Origin: National Statistics Institute of Spain [7].

average daily expenditure per tourist (Euros) in La Manga

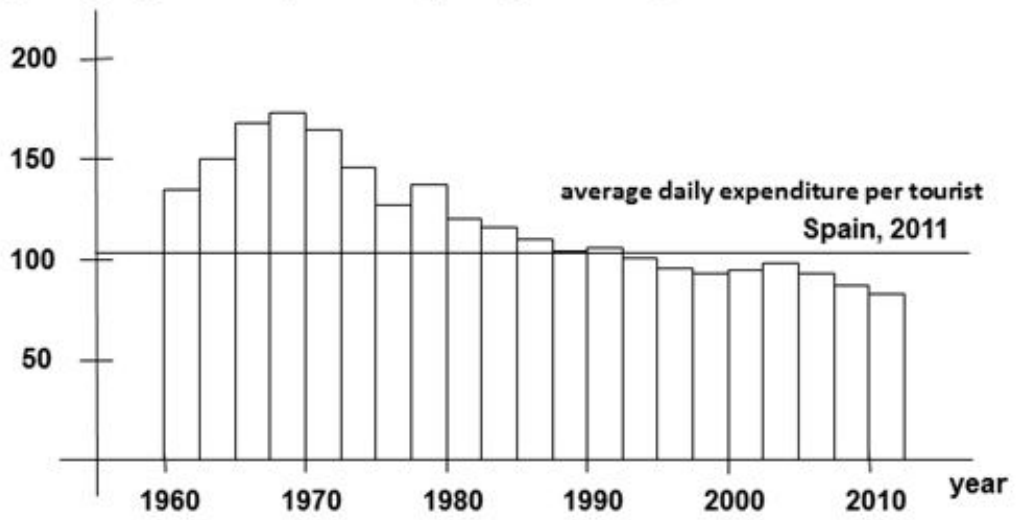

Figure 10: Average daily expenditure per tourist in La Manga (Euros) vs average in Spain in 2011. Origin: the authors.

\section{Conclusions}

According to the analysis of the case of La Manga, we can draw the following conclusions:

- From the point of view of governance, the accumulation of power in local government and the excessive freedom of action of private property are not beneficial to sustainable urban development tourism or 
development to long run. The particular pressures on decision making generate planning policies with short-term visions.

- $\quad$ From a planning point of view, deregulation or lack of control of urban growth process leads to overcrowding. This overcrowding produces in the long term degradation of space and loss of quality of the environment and tourism services.

- From economic point of view, the process of urban overcrowding can produces a profit in the short term, but finally produces a loss of urban product value in the long term with declining revenue.

The case of La Manga is a representative sample to draw general conclusions for the entire Spanish Mediterranean coast. However, it represents a very instructive example of the negative effects that can have a poorly managed tourism project. It demonstrates the need for reflection and urban analysis, social and economic about coast macro-projects to assess their consequences. This need for diagnostic parameters for long-term evaluation is especially imperative now when back in Spain are proposed as potential solutions to the current crisis, the promotion of new macro-projects on the Mediterranean coast as Valdevaqueros in Cadiz, Marina d'Or Golf in Castellón, Mirador on Mallorca Es Trenc or Marina Cope in Murcia.

\section{References}

[1] García-Ayllón S. En los procesos de urbanización del mediterráneo: el caso La Manga. PhD thesis, Polytechnic University of Valencia (Spain), 2012 (in process for defence).

[2] Galiana L. and Barrado D. Los centros de interés turístico nacional y el despegue del turismo de masas en España. Investigaciones Geográficas, 39, pp. 73-93, 2006.

[3] López-Morell, M.A., Pedreño Cánovas, A. and Baños Páez, P. Génesis y trayectorias del desarrollo turístico del entorno del Mar Menor. VIII Congreso de la AEHE. A Coruña University: A Coruña, 2005.

[4] Rullán Salamanca, O. La regulación del crecimiento urbanístico en el litoral mediterráneo español. Revista Ciudad y Territorio, 168, 2011.

[5] Miralles i Garcia, J.L. Real estate crisis and sustainability in Spain. Proc of the Sustainable Development and Planning V, eds. C.A. Brebbia and E. Beriatos, WIT Press: Southampton, pp. 123-133, 2011.

[6] ST - Sociedad de Tasación, www.st-tasacion.es/es/informacion-mercado/ evolucion-precios-vivienda-nueva.html

[7] National Statistics Institute of Spain, www.ine.es/inebmenu/mnu construc.htm

[8] Miralles i Garcia, J.L., Díaz Aguirre, S. and Altur Grau, V.J. Environmental impact on the Mediterranean Spanish coast produced by the latest process of urban development. WIT Transactions on Ecology and The Environment, Vol 155, WIT Press: Southampton, pp. 379-389, 2012.

[9] Steinitz, C. Environmental Planning for Communities. Technology Transfer and Support Division, Office of Research and Development, United States Environmental Protection Agency: Cincinnati, Ohio, 2000. 